\title{
Proximal Row Carpectomy in Hand Replantation: A Case Report
}

\author{
Danijel Raspopovic ${ }^{1 *}$, Dejan Tabakovic ${ }^{2}$ and Radovan Manojlovic ${ }^{2}$ \\ ${ }^{1}$ Hospital for Orthopedic Surgery and Traumatology, Serbia \\ ${ }^{2}$ Clinical Center of Serbia, Serbia
}

Submission: February 06, 2017; Published: February 14, 2017

*Corresponding author: Danijel Raspopovic, Hospital for Orthopedic Surgery and Traumatology, Serbia.

\begin{abstract}
Proximal or first row carpectomy is a motion-preserving treatment for the degenerated wrist. Proximal row carpectomy provides painless wrist range of motion with few complications [1]. The loss of a hand is a devastating but not so common injury with a huge array of effects. Beyond the obvious potential for the loss of support are profound social, psychological, and aesthetic consequences [2].
\end{abstract}

\section{Case Report}

We present a case of 34 years old right/hand/dominant male patient was injured in December 2007 with the cutting metal machine in an aluminum manufacturing factory about 200 miles away from Belgrade. He arrived at our Trauma center 4 hours after being injured, conscious, communicative and well oriented. The amputated hand was brought in a nylon bag placed in a small mobile refrigerator filled with ice cubes. After clinical and radiological examination of the amputated hand, the patient was accepted for hand replantation [3] (Figure 1). In preparation for the surgery radiographs were taken and they revealed amputation at the midcarpal level, intravenous fluids and tetanus immunoglobulin were administered as well as antibiotics, combination of ceftriaxone sodium, gentamicin and metronidazole by intravenous infusion, starting at the time of admission to the hospital. Anti-tromboembolic prophylaxis was also administered using low molecular weight heparin, Fraxiparine (Figure 2). Careful lavage of both amputated hand and proximal wrist with more than three litres of natriumsodium solution was obtained followed by careful examination of both anatomical regions. Tourniquet was applied, necessary bone shortening, in this case we found to be possible only with first row carpectomy, performed and followed with stabilization with two $3.2 \mathrm{~mm}$ Steinman pins. Because of better functional postoperative status and uninjured distal radius articular surface we have decided not to shorten distal radius or distal carpal bones. Soft tissue debridement was conducted together with identifying of arteries, veins, nerves and tendons (Figure 3). Superficial flexor tendons were also debrided. Radial artery was first anatomical structure to be sutured, followed by reconstruction of flexor tendons, both radial and ulnar nerve, extensor tendons and only one vein [4-6] (Figure 4).

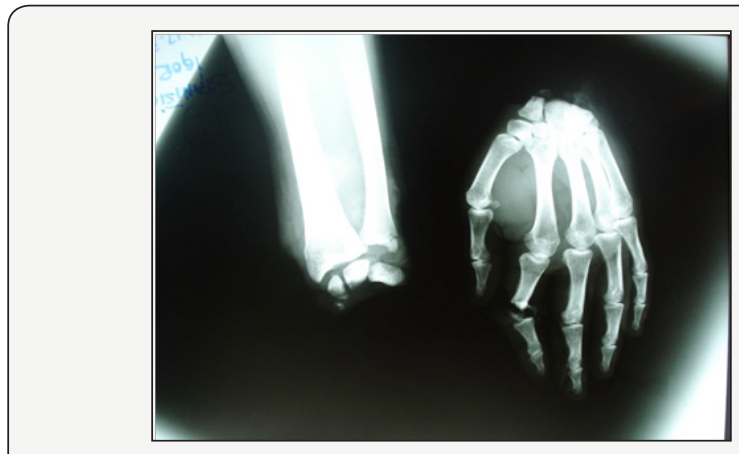

Figure 1: X-Ray showing broken hand.

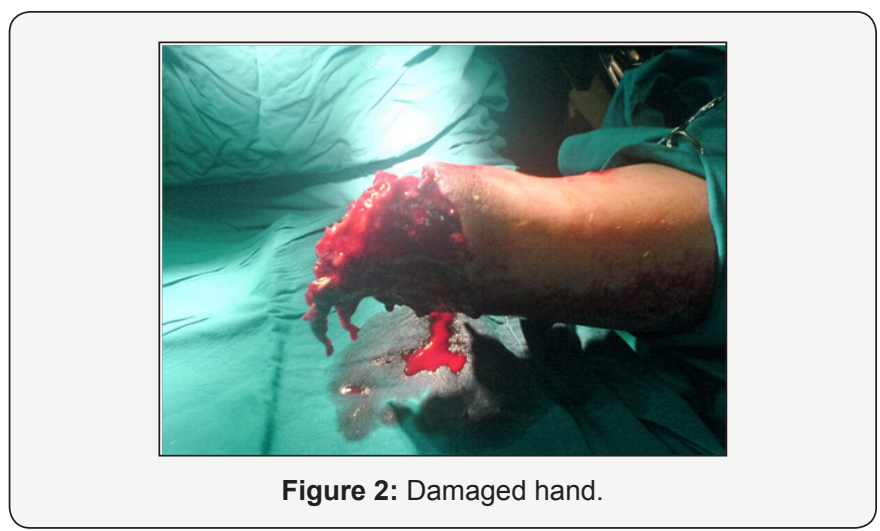



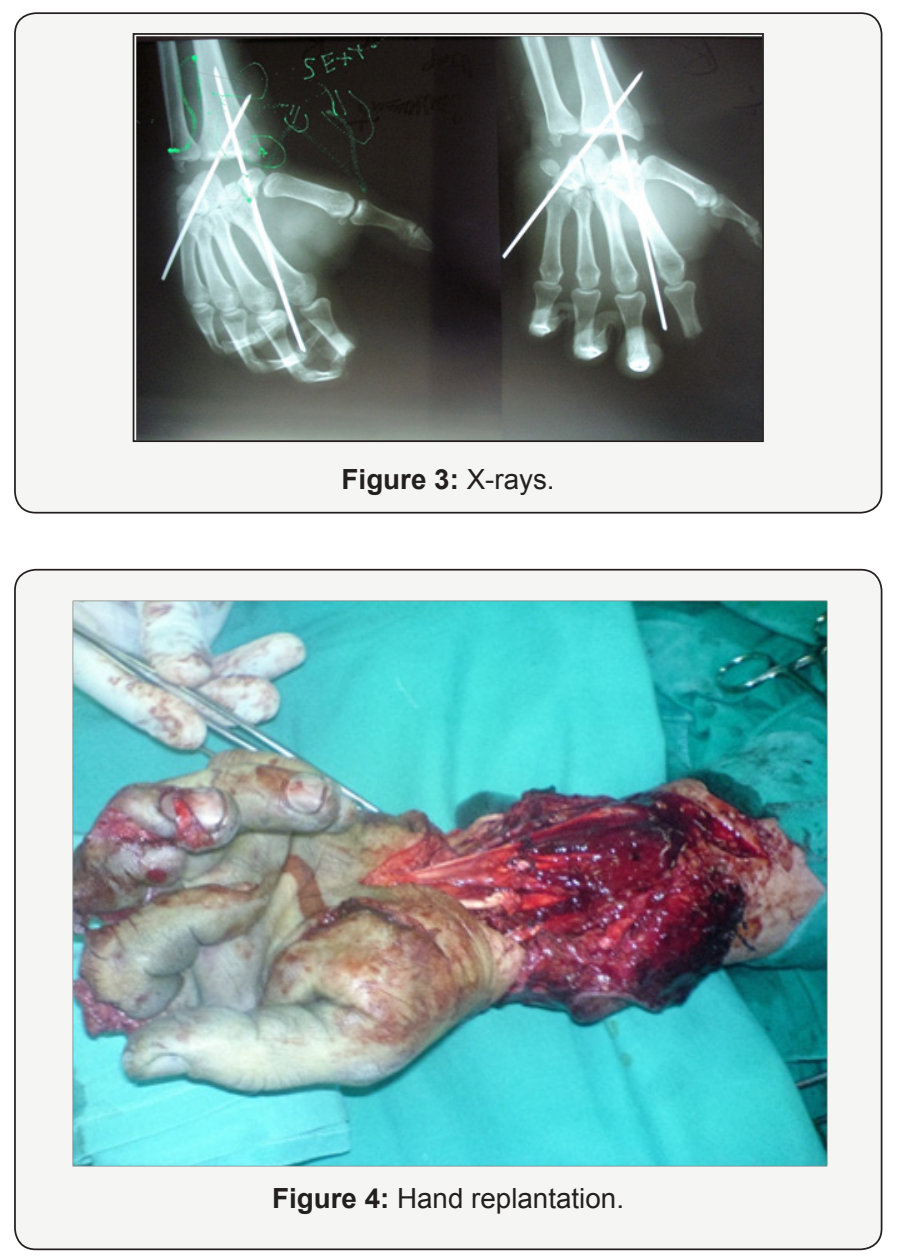

\section{Discussion}

In our patient, the follow- up period was 3 months, so complete assessment of the sensory and motor function recovery was not viable at this time period. However, the patient has started to exhibit minimal flexion and extension movements at the wrist, metacarpophalangeal and interphalangeal joints and signs of initial sensory recovery, such as rough touch.

\section{Ethics}

The Ethical Committee approval was searched for this article.

\section{Declaration of conflicting interests}

The author has no conflict of interest to disclose and no relationships to industry related to this research.

\section{Funding}

This research received no specific grant from any funding agency in the public, commercial, or not-for-profit sectors.

\section{References}

1. Lindley B Wall, Peter J Stern (2013) Proximal row carpectomy. Hand Clinics 29(1): 69-78.

2. Poore SO, Israel JS, Rao VK (2016) Thirty-Year Follow-up of Total Hand Replantation: A Case Report. Ann Plast Surg 76(5): 521-523.

3. Pederson WC (2001) Replantation. Plast Reconstr Surg 107(3): 823841.

4. Vucetic CS, Vukasinovic Z, Miric D, Tulic G (2006) Two cases of big-toe replantation: a ten-year follow-up. J Reconstr Microsurg 22(2): 79-86.

5. Weiland AJ, Villarreal Rios A, Kleinert HE, Kutz J, Atasoy E, et al. (1977) Replantation of digits and hands: analysis of surgical techniques and functional results in 71 patients with 86 replantations. J Hand Surg Am 2(1): 1-12.

6. Vucetic CS (2005) Forearm elongation after hand replantation. A case report. J Bone Joint Surg Am 87(1): 181-186.

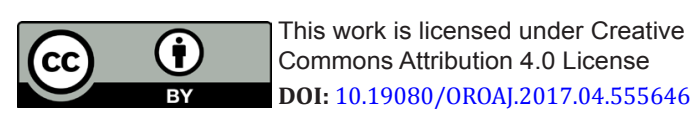

\begin{tabular}{l} 
Your next submission with Juniper Publishers \\
will reach you the below assets \\
- Quality Editorial service \\
- Swift Peer Review \\
- Reprints availability \\
- E-prints Service \\
- Manuscript Podcast for convenient understanding \\
- Global attainment for your research \\
- Manuscript accessibility in different formats \\
( Pdf, E-pub, Full Text, Audio) \\
- Unceasing customer service \\
Track the below URL for one-step submission \\
https://juniperpublishers.com/online-submission.php \\
\hline
\end{tabular}

